\title{
Molecular cloning and characterization of a proliferating cell nuclear antigen gene by chemically induced male sterility in wheat (Triticum aestivum L.)
}

Y.A. Yu, G.S. Zhang, J. Zhang, L. Ju, Q.D. Zhu, Y.L. Song, J.W. Wang, N. Niu and S.C. Ma

College of Agronomy, Northwest A\&F University,

National Yangling Agricultural Biotechnology \& Breeding Center,

Yangling Branch of State Wheat Improvement Center,

Wheat Breeding Engineering Research Center, Ministry of Education,

Key Laboratory of Crop Heterosis of Shaanxi Province, Yangling, Shaanxi, China

Corresponding author: G.S. Zhang

E-mail: zhanggsh58@aliyun.com

Genet. Mol. Res. 14 (4): 12030-12042 (2015)

Received January 29, 2015

Accepted May 18, 2015

Published October 5, 2015

DOI http://dx.doi.org/10.4238/2015.October.5.16

ABSTRACT. Although a number of studies have shown that chemical hybridizing agents (CHAs) affect anther growth and regulate cell-cycle progression, little is known about the molecular and cellular mechanisms involved. Proliferating cell nuclear antigen (PCNA) is an essential factor in DNA replication, and in many other processes in eukaryotic cells. In this study, the open reading frame of TaPCNA, the PCNA in wheat (Triticum aestivum L.), was cloned by reverse transcription polymerase chain reaction (RT-PCR). Sequence analysis revealed that this gene was 792-bp long and encoded a protein with 234 amino acids. Alignment of the TaPCNA-predicted sequence revealed a high degree of identity with $P C N A$ s from other plant species. A subcellular localization assay indicated that TaPCNA was localized in the nucleus. The TaPCNA was cloned into the prokaryotic expression plasmid pET32a, and the recombinant plasmid was 
transformed into BL21 (DE3). TaPCNA expression was induced by $0.5 \mathrm{mM}$ isopropyl-beta-D-thiogalactopyranoside and verified using sodium dodecyl sulfate polyacrylamide gel electrophoresis and western blot assays, which indicated that the fusion protein was successfully expressed. The gene involved in the G1-to-S transition, Histone H4, was downregulated by 1376 CIMS, which is a chemically induced male sterility line. However, a semiquantitative RT-PCR revealed that TaPCNA expression was upregulated in 1376-CIMS. Our results suggest that $\mathrm{CHAs}(\mathrm{SQ}-1)$ induce DNA damage in wheat anthers. DNA damage results in either the delay or arrest of cellcycle progression, which affects anther development. This study will help to elucidate the mechanisms of SQ-1-induced male sterility.

Key words: Triticum aestivum L.; Chemical hybridizing agent SQ-1; Male sterility; Cell cycle; Proliferating cell nuclear antigen

\section{INTRODUCTION}

Chemically-induced male sterility (CIMS) is based on the use of certain chemicals known as chemical hybridizing agents (CHAs) (Chakraborty and Devakumar, 2005). They are useful breeding tools, because they allow crosses to be made without laborious hand emasculation. Despite the fact that some progress has been made in cytoplasmic male sterility (Sasakuma et al., 2001; Zhang et al., 2009), little information on the regulatory mechanism of CHAs that causes male sterility is available.

Reactive oxygen species (ROS) are toxic molecules that are continuously produced in cells during aerobic metabolism. The evolution of aerobic metabolic processes, such as respiration and photosynthesis, unavoidably led to the production of ROS in mitochondria, chloroplasts, and peroxisomes (Apel and Hirt, 2004; Mittler et al., 2004). The production and removal of ROS must be strictly controlled. However, the equilibrium between ROS production and scavenging may be perturbed by a number of adverse abiotic stress factors such as drought, bright light, high temperature, low temperature, and mechanical stress (Malan et al., 1990; Prasad et al., 1994; Tsugane et al., 1999). If ROS are not promptly cleared, the organism will suffer oxidative stress, resulting in protein and nucleic acid damage, lipid peroxidation, and even cell death (Foyer and Noctor, 2000). In a previous study, we found that cyanide-resistant respiration in the anthers of Xinong 1376-CIMS was weaker than that in normal Xinong 1376 anthers; we then investigated the relationship between ROS metabolism and CIMS systems in wheat. The results indicated that 1376-CIMS anthers had higher levels of $\mathrm{O}_{2}, \mathrm{H}_{2} \mathrm{O}_{2}$, and MDA than those of 1376 (Ba et al., 2013). It was shown that an unbalance in ROS metabolism was closely related to pollen abortion and physiological male sterility in wheat.

DNA repair is coordinated with cell-cycle progression (Hoeijmakers, 2001; Friedberg et al., 2004) and DNA damage checkpoints (Bartek et al., 2004). DNA damage checkpoints delay mitotic cell-cycle progression in response to DNA stress, stalling the cell cycle to allow time for repair. The proliferating cell nuclear antigen (PCNA) is a cell-cycle marker, and is an evolutionarily conserved protein in all eukaryotic species (Strzalka et al., 2010). Advanced studies on PCNA have revealed its crucial role not only in DNA replication but also in DNA repair, cell-cycle control, and other processes (Tuteja et al., 2001; Stoimenov and Helleday, 2009; Strzalka and Ziemienowicz, 
2011). DNA repair is a process in which many details of PCNA involvement have been described; further information can be obtained from several recent reviews (Friedberg et al., 2005; Moldovan et al., 2007). In the case of nucleotide excision repair (NER), PCNA binds to the endonuclease XP-G through a PIP box located in the C-terminus, possibly allowing PCNA to coordinate DNA excision and DNA synthesis. In base excision repair (BER), the PCNA-dependent DNA pol $\delta / \beta$ mediated repair pathway of abasic sites in Xenopus laevis (long-patch BER) has been employed as an alternative mechanism to the DNA polß-mediated pathway (Matsumoto et al., 1994, 1999). In studies on yeast and mammalian proteins, PCNA has been found to interact with MSH3 and MSH6 in mismatch repair (MMR). Moreover, PCNA and MSH2-MSH6 have been shown to form a stable ternary complex that stimulates the preferential binding of MSH2-MSH6 to mispaired DNA bases. Therefore, PCNA plays a key role in three DNA repair pathways (NER, BER, and MMR), and functions by direct interaction with various proteins involved in these processes.

In this study, we report the identification of PCNA in wheat, and used 1376-CMIS and 1376 anthers to study the expression of TaPCNA at different developmental stages, in order to investigate the internal relationship between wheat CIMS and DNA damage. The findings of this study will help us to understand the how CHAs cause male sterility.

\section{MATERIAL AND METHODS}

\section{Plant materials and microscopic observation}

A typical CIMS line, Xinong 1376-CIMS ("1376-CIMS" for short), that was induced by the CHA SQ-1, which is a new chemical hybridizing agent, and the fertile line Xinong 1376 ("1376" for short), both with identical genetic backgrounds, were grown in the experimental fields of Northwest A\&F University, Shaanxi, China. When average wheat development was at the 8.5 stage of the Feekes scale (Liu et al., 2003), the CIMS line was sprayed with $5.0 \mathrm{~kg} / \mathrm{ha}$ SQ-1. To establish cytological controls, the purity and developmental stage of the pollen was checked by staining with $1 \%$ acetocarmine ( $1 \%$ carmine in $45 \%$ aqueous acetic acid) and 4',6-diamidino-2-phenylindole (DAPI). Pollen fertility and viability were tested with iodine-potassium iodide $\left(\mathrm{KI}-\mathrm{I}_{2}\right)$ assays and Alexander's stain (Alexander, 1969).

\section{Isolation and bioinformatics analysis of TaPCNA}

Total RNA was isolated from anthers using a TRIZOL reagent solution (Invitrogen, USA), and treated with RNase-free DNase I (Takara, China) to remove DNA contamination. Approximately $1 \mu \mathrm{g}$ total RNA was reversely transcribed into cDNA using the PrimeScript ${ }^{\mathrm{TM}} \mathrm{RT}$ reagent kit (Takara), according to the manufacturer instructions.

To isolate cDNAs that encode homologues of PCNA from $T$. aestivum, the rice OsPCNA (X54046) sequence was used as a query to search the wheat sequence database (http://www.ncbi.gov.cn). The full-length TaPCNA gene was cloned using the forward primer 5'-ATGTTGGAGCTGAGGCTG-3' and reverse primer 5'-TCATGCCTTCATTTCCTC-3'. Polymerase chain reactions (PCRs) were performed in mixtures containing: $1 \mathrm{X}$ reaction buffer, $2.5 \mathrm{mM} \mathrm{MgCl}$, $200 \mu \mathrm{M}$ dNTPs, $0.15 \mu \mathrm{M}$ of each primer, $1 \cup$ Taq polymerase (Takara), and $100 \mathrm{ng}$ cDNA, in a total volume of $20 \mu \mathrm{L}$. The PCR amplification was as follows: initial denaturation at $94^{\circ} \mathrm{C}$ for $3 \mathrm{~min}$, followed by 35 cycles at $94^{\circ} \mathrm{C}$ for $40 \mathrm{~s}, 52^{\circ} \mathrm{C}$ for $45 \mathrm{~s}, 72^{\circ} \mathrm{C}$ for $40 \mathrm{~s}$, an extension cycle at $72^{\circ} \mathrm{C}$ for 
5 min, and termination of the reaction at $4^{\circ} \mathrm{C}$. The resulting PCR products were purified and cloned into the $\mathrm{pGM}^{\circledast}-\mathrm{T}$ vector (Tiangen, China). Multiple sequence alignments of the deduced amino acid sequences were conducted using the DNAMAN software. A phylogenetic tree was constructed using MEGA (5.0). The theoretical isoelectric point ( $\mathrm{pl})$ and molecular weight $(\mathrm{Mw})$ were predicted using ExPASy (Expert Protein Analysis System, http://www.expasy.org/tools).

\section{Subcellular localization}

To observe subcellular localization, the coding regions of TaPCNA were amplified with the following primers: P1, 5'-GAAGATCTATGTTGGAGCTGAGGCTG (Bg/ll) and P2, 5'GGACTAGTTGCCTTCATTTCCTCATC (Spel). The PCR products were cloned into the pGM $^{\circledR}-T$ vector (Tiangen), digested with Bg/ll and Spel, and then cloned into the expression vector pceGFP. The resultant construct p35S:TaPCNA-GFP and the control vector p35S:GFP were genetically introduced into onion epidermal cells by an Agrobacterium-mediated transformation. Following pre-incubation at $26^{\circ} \mathrm{C}$ for $48 \mathrm{~h}$, the onion epidermal cells were visualized using a fluorescence microscope (DM500 B, Leica, Germany).

\section{Semi-quantitative reverse transcription polymerase chain reaction (RT-PCR) gene expression analysis}

A semi-quantitative RT-PCR was used for measuring transcript levels of TaPCNA in this study. Total RNA was isolated from anthers at different developmental stages in 1376-CIMS and the fertile line 1376. The following specific primers were used for RT-PCR amplification: TaPCNA-F, 5'-TGACAAGCCTGAGGAATC-3' and TaPCNA-R, 5'-GTAGCCCATCTCGCCAATC-3'. The internal control primers that were designed to amplify the 18S rRNA gene (AY049040) were 5'-AGTAAGCGCGAGTCATCAGCT-3' and 5'-CATTCAATCGGTAGGAGCGAC-3'.

\section{Construction of the prokaryotic expression vector}

The prokaryotic expression vector pET32a-TaPCNA was constructed by PCR with $\mathrm{PGM}^{\circledR}-\mathrm{T}-\mathrm{Ta} P C N A$ as a template, and the primers were as follows: P3, 5'-CGAGCTCATGTTGGAGCTGAGGCTG-3' (Sacl) and P4, 5'-CCCAAGCTTTGCCTTCATTTCCT CATC-3' (HindIII). The PCR-amplified fragments were purified, doubly digested with Sacl and HindIII, ligated with the pET32 plasmid, and doubly digested with the same restriction enzymes to generate the prokaryotic expression vector. The recombinant plasmid was confirmed by restriction enzyme digestion and sequencing. The correct recombinant plasmid was named pET32-TaPCNA.

\section{Recombinant protein expression}

The pET32a-TaPCNA was transformed into Escherichia coli BL21 (DE3, Novagen). The selected colony was grown in $100 \mathrm{~mL}$ lysogeny broth medium containing $1 \%(\mathrm{w} / \mathrm{v})$ glucose and 50 $\mu \mathrm{g} / \mathrm{mL}$ ampicillin, and was then incubated at $37^{\circ} \mathrm{C}$ with vigorous shaking (180 r/min), until the optical density at $600 \mathrm{~nm}$ reached 0.6 . Expression of the recombinant protein was induced by the addition of $0.5 \mathrm{mM}$ isopropyl-beta-D-thiogalactopyranoside (IPTG) and cultured for $4 \mathrm{~h}$. Subsequently, $1 \mathrm{~mL}$ 
cells was harvested by centrifugation at $10000 \mathrm{~g}$ for $5 \mathrm{~min}$. The pellets were suspended in $0.1 \mathrm{M}$ phosphate-buffered saline (PBS; $\mathrm{pH}$ 7.4). The cell pellets were subjected to sodium dodecyl sulfate polyacrylamide gel electrophoresis (SDS-PAGE) to analyze the expression of the recombinant proteins.

\section{Western blot analysis of the recombinant protein}

For western blotting, the proteins were separated by SDS-PAGE gels and then transferred to a polyvinylidene difluoride membrane by an electrophoretic transfer system (Bio-Rad). The membrane was washed in PBS, blocked with milk buffer $(20 \mathrm{mM}$ Tris- $\mathrm{HCl}, \mathrm{pH}$ 8.0, $150 \mathrm{mM} \mathrm{NaCl}$, $0.05 \%$ Tween 20 , and $5 \%$ dry skimmed milk) for $1 \mathrm{~h}$ at $37^{\circ} \mathrm{C}$, and incubated with anti-His-tag mouse monoclonal antibody (Tiangen) diluted 1:5000 in $0.5 \%$ bovine serum albumin/PBS for $1 \mathrm{~h}$ at $37^{\circ} \mathrm{C}$. It was then washed twice in TBST and incubated with a HRP-labeled sheep anti-mouse IgG for $1 \mathrm{~h}$ at $37^{\circ} \mathrm{C}$. After washing with TBST three times, target proteins were visualized using 3,3'-diaminobenzidine (DAB) (Tiangen).

\section{RESULTS}

\section{Identification of male sterility induced by SQ-1}

In order to collect synchronous anther samples for analysis of each discrete developmental stage, and to establish cytological controls, it was essential to confirm the precise cytological stage of microspore development. The cytological results of wheat microspore development using acetocarmine staining techniques and DAPI are shown in Figure 1a-f; we observed pollen fertility by using potassium iodide-starch and Alexander's stain (Figure 1g-j). At the mature pollen stage, pollen grains stained with $\mathrm{I}_{2}-\mathrm{KI}$ revealed that starch filling was completed in the fertile line (1376) but there was no starch accumulation in 1376-CIMS. Using Alexander's stain, viable pollen grains are purple with a green outline, and aborted pollen grains are green on the inside and the outside. The basis for this differential staining may be a $\mathrm{pH}$ difference in the cytoplasm between live and dead pollen. Pollen grains from the fertile line 1376 were full, round, purple-stained grains with a green outline. However, pollen grains from 1376-CIMS were a mixture of purple grains with a green outline and green, misshapen grains.

\section{Cloning and sequence analysis of TaPCNA}

In order to isolate PCNA from wheat, rice OsPCNA (X54046) was used as a query to search the wheat EST database. The results showed that only one specific DNA band was visualized by agarose electrophoresis (Figure 2a). The cDNA sequence of TaPCNA contained a 792-bp open reading frame that encoded a polypeptide with 263 amino acids. The calculated $\mathrm{Mw}$ of the polypeptide was $29.16 \mathrm{kDa}$ and the $\mathrm{pl}$ was 4.53. Multiple sequence alignments of TaPCNA and PCNA from other plants revealed that they were highly homologous (Figure 3 ). A phylogenetic tree constructed using PCNAs of 16 plant species showed that TaPCNA was grouped in the same cluster as Oryza sativa L. (Figure 4). The sequence obtained in this study has been submitted to the GenBank database, and was assigned the GenBank accession No. KM087781. 

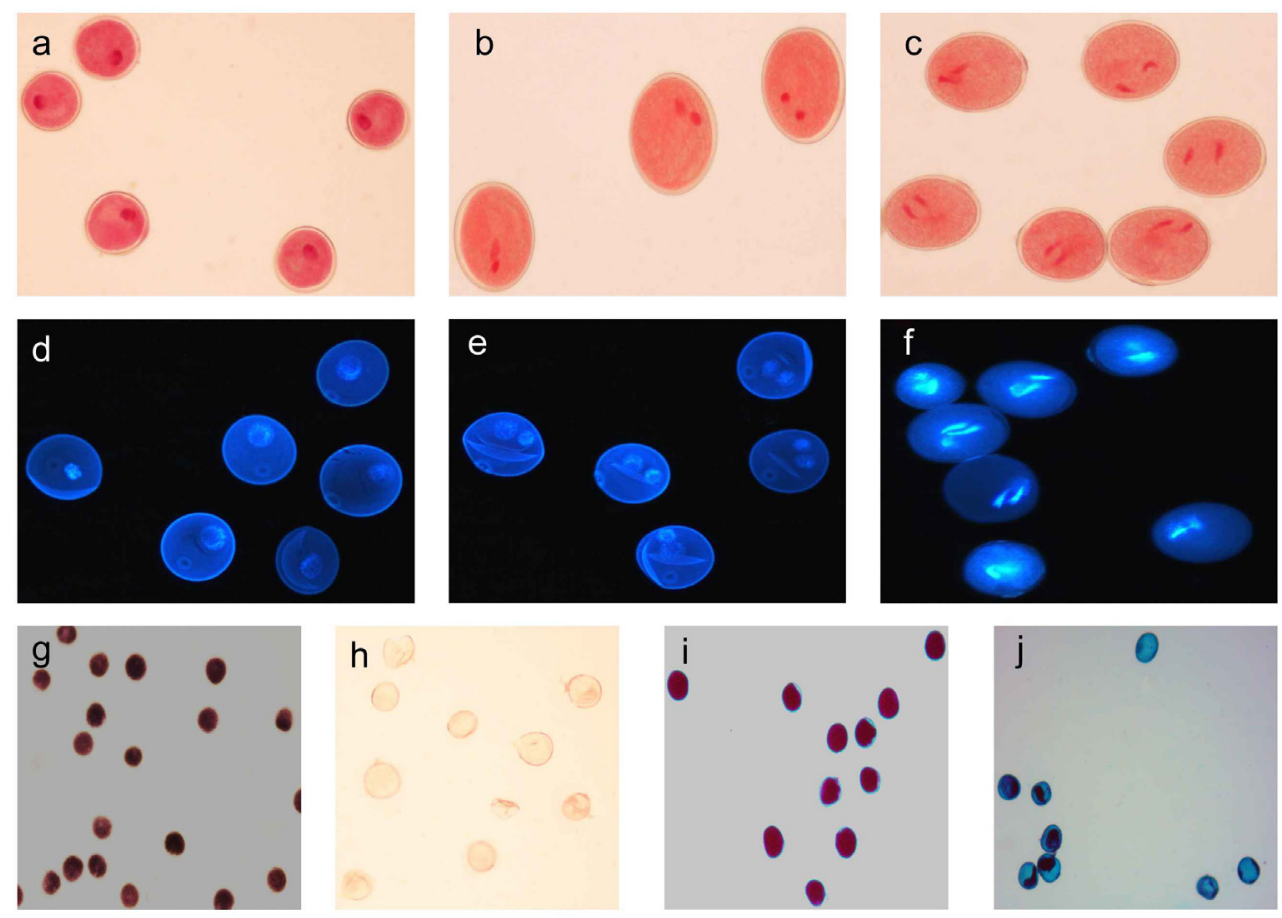

Figure 1. Microspore development and pollen fertility of $1376-\mathrm{CIMS}$ as compared to 1376. a.-c. Stained with acetocarmine; d.-f. stained with 4',6-diamidino-2-phenylindole; g. and h. stained with potassium iodide-starch; i. and j. stained with Alexander's stain; $a$ and $d$, uninucleate microspore; $b$ and e, binucleate microspore; $c$ and $f$, trinucleate microspore; $g$ and $\mathrm{I}$, pollen from 1376; $\mathrm{h}$ and $\mathrm{j}$, pollen from 1376-CIMS.
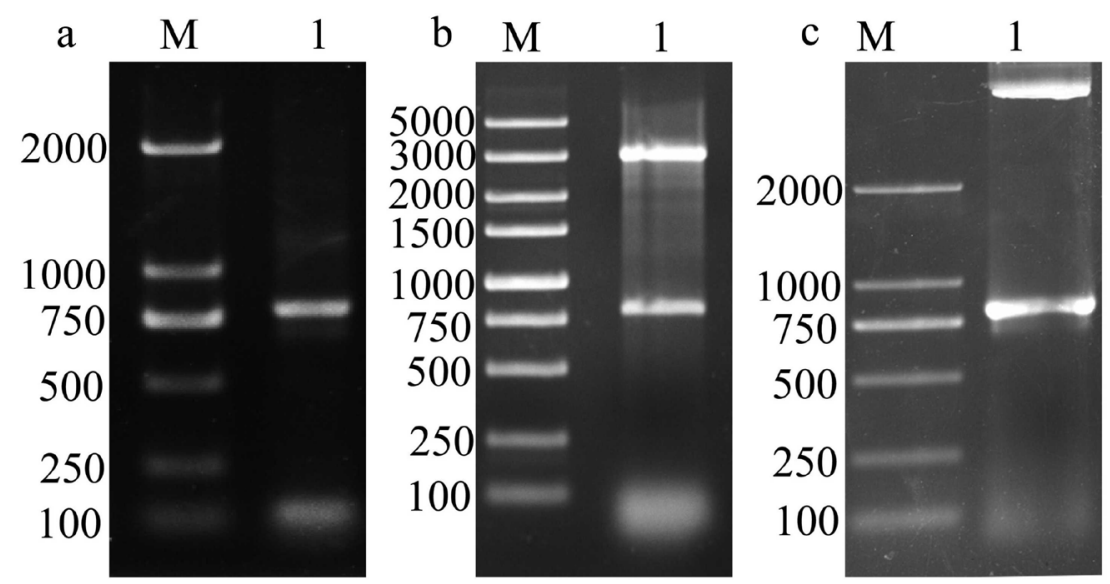

Figure 2. a. Cloning of the TaPCNA gene fragment. Lane $M=\mathrm{DL} 2000$; lane $1=\mathrm{Ta} P C N A$ gene fragment. $\mathbf{b}$. Identification of the forward vector pGM ${ }^{\circledR}-\mathrm{T}-\mathrm{TaPCNA}$ by Sacl and Hindlll digestion; lane M = DL5000; lane $1=$ pGM $^{\circledR}-\mathrm{T}$-TaPCNA digested with Sacl and Hindlll. c. Identification of the forward vector pET32a-TaPCNA by Sacl and Hindlll digestion; lane 1 = pET-32a-TaPCNA digested with Sacl and HindIII; lane M = DL2000. 


\begin{tabular}{|c|c|c|}
\hline T.aestivum & MLELRLVQGSLLKKVLEAIRELVIDANEDCSGIGFSLQAMDSSHVALVALLLRSEGEEY & 60 \\
\hline P. tomentosa & DCSSSGESLQAMDSSHVALVALLLFSEGFEHY & 60 \\
\hline P.vulgaris & TGESLCQAMDSSHVALVGLLLFSEGFEHY & 60 \\
\hline G.max & MLELRLVQ GSLLKKVLESVRELVNDANFDCSSTGESLQAMDSSHVALVALLLRSEGFEHY & 60 \\
\hline S.lycopersicum & MLELRLVQQGSLLKKVLESIKLLVNDANF DCSATGFSLQAMDSSHVALVALLLRSEGFEHY & 60 \\
\hline D. carota & MLELRLVCQGSLLKKVMLSIRLLVNDANFDCSATGESLCQAMDSSHVALVAVLLRSEGFEHY & 60 \\
\hline A.thaliana & MLELRLVQ্রSLLKKVLESIRLLVNDANFDCSSTGFSLQQAMDSSHVALYSLLLRSEGEEHY & 60 \\
\hline B.napus & SLLVNDANFDCSTIGFSLQ̊AMDSSHVALVSILL & 60 \\
\hline 0.sativa & IEAIRELVIDANFDCSGTGFSLQAMDSSHVALVALLLRSEGEEHY & 60 \\
\hline P.sativum & 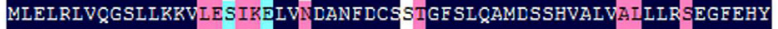 & 60 \\
\hline N.tabacum & MLELRLVCQGSLLKKVLESIRLLVNDANFDCSATGFSLQAMDSSHVALVALLLRSEGFEHY & 60 \\
\hline 2.mays & MLELRLVCGSLLKKVLEAIRELVNDANFDCSGIGFSLQAMDSSHVALVALLLRZEGFEHY & 60 \\
\hline T.aestivum & DEGSDTVTFMFESENQDKIZDFEMRLMD & 120 \\
\hline P.tomentosa & NDDI ITIRGDDGSDTVTFMFESETQDKIZDFEMRLMD & 120 \\
\hline P.vulgaris & RMLRCAGNDDIITIKZDDEGDTVTFMFESETQDRISDFEMRLMD & 120 \\
\hline G. $\max$ & DDESDTVTFMFESETQDKISDEEMRLMD & 120 \\
\hline S.lycopersicum & RCDRN ISMGMNITNMZKMLKCAGNDDI ITIKZDLGSDTVT FMFESETQDKIZDFEMKLMD & 120 \\
\hline D. carota & RCDRN ISMGMNI GNMZRMIKCAGNDDI ITIKZDDGSDTVT FMFESEICDKIZDFEMRLMD & 120 \\
\hline A. thaliana & RCDRNISMGMNIGNM SKMIXCAGNDDI ITIKZDDGEDTVT FMFESETQDKIZDFEMKLMD & 120 \\
\hline B.napus & RCDRNISMGMNIGNMSKMIKCAGNDDIITIKZDDGCDTVTFMFESEKQDKIZDFEMRLMD & 120 \\
\hline 0. sativa & RCDRNISMGMNIMNMZKMIFCAGNDDIITIKZDDGSDTVT FMFESENQDKIZDDFEMRLMD & 120 \\
\hline P.sativum & RCDRNISMGMNINNM ZKMLXCAGNDDIITIK & 120 \\
\hline N.tabacum & DDGSDTVTFMFESETQDKIZDFEMRLMD & 120 \\
\hline Z.mays & RCDRNI SMGMNINNM KMI RCAGNDDI ITIKZDDGSDTVTFMFESEKQDKIZDFEMKLMD & 120 \\
\hline T.aestivum & GVKFSTEGIIETANI & 180 \\
\hline P. tomentosa & KEGVKFSTRELIEIANI & 180 \\
\hline P.vulgaris & KEGVRFSTEGLIESANI & 180 \\
\hline G.max & VTKEGVRESTKGLIETANI & 180 \\
\hline S.lycopersicum & EAGRICKDLSSIGDTVVISVTKEGVKFSTREDIGIANI & 180 \\
\hline D. carota & KEGVRESTREDIEIANI & 180 \\
\hline A. thaliana & REGVRFSTZGLIGTANI & 180 \\
\hline B.napus & REGVRESTZGDIGIANI & 180 \\
\hline O.sativa & KEGVRFSTPEDIGTANI & 180 \\
\hline P.sativum & REGVRESTKGDIGSANI & 180 \\
\hline N.tabacum & REGVRFSTFELIGTANI & 180 \\
\hline 2.mays & SSIGDTVVISVIKEGVKFSISGEIGSRNI & 180 \\
\hline T.aestivum & PVSITFALRYMNSFTRZISELSE & 240 \\
\hline P.tomentosa & TFALRYMNSFTKZTELSNTVISLSSELPVVVEYK & 240 \\
\hline P.vulgaris & TFALRYMSFTKRTELSNTVSISLSNELPVVVEYK & 240 \\
\hline G.max & TVIISLSNELPVVVEYK & 240 \\
\hline S.lycopersicum & DSITEALRYLNSFTKRSELSNTVISLSSELPVVVEYK & 240 \\
\hline D. carota & VSITFALRYMNETKZSELSSTVIISLSSELFVVVEYK & 240 \\
\hline A. thaliana & 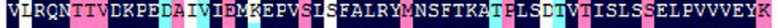 & 240 \\
\hline B.napus & EPVSISFALRYMNETKATALSDTVISLSSELPVVVEYK & 240 \\
\hline O.sativa & SIIFALRMUNSTKZSELSEOVIISLSSELPVVVEYK & 240 \\
\hline P.sativum & WICEALRYMNETRZTELSSSVIISLSNELFVVVEYK & 240 \\
\hline N.tabacum & VORQNTTVDKPEEATVIDUNEPVSITFALRYLNSFTRZT TELSNTVTISLSSELPVVVEYK & 240 \\
\hline 2.mays & CXEVSITEALRYMSFTRZSSLSECVIISLSSELPVVVEYK & 240 \\
\hline T.aestivum & IGEMGYIR FYLAPRIEELDEMRA . . & 263 \\
\hline P.tomentosa & IZEMSYZFYYLAPRIDEDEDENGD. & 264 \\
\hline P.vulgaris & IZEM CYVEFYLAPKIDEDDEE . KPQ & 264 \\
\hline G.max & IZEM CYVEFYLAPKIDEDDEDTKPQ & 265 \\
\hline s.lycopersicum & IZEM GYVEYYLAPKIDEDBEETKP. & 264 \\
\hline D. carota & IZEMGYIRFYLAPKIBEEEDESKP. & 264 \\
\hline A.thaliana & VZEMEYIRYYLAPKIDEDEDTNP. . & 263 \\
\hline B.napus & VPEMGYIFYYLAPKIDEDEEDKA . . & 263 \\
\hline o.sativa & IZEMGYIR FYLAPKIBEDEEMKS. . & 263 \\
\hline P.sativum & IZEMGYVRFYLAPKIDELBEETKPQ & 265 \\
\hline N.tabacum & IZEM EYIR FYLAPKIBEDBEETKR. & 264 \\
\hline 2. mays & IZEY EYIREYLAPKIDLDEEMRP . . & 263 \\
\hline
\end{tabular}

Figure 3. Multiple alignments of the deduced amino acid sequence of TaPCNA and PCNA proteins from other plants. GenBank accession Nos. for the proteins are as follows: TaPCNA (KM087781), Pt (AY836671), Pv (XM_007147532), Gm (NM_001254624), SI (NM_001247915), Dc (Q00268), At (NM_100611), Bn (Q43124), Os (NM_001054973), Ps (O82134), Nt (AJ012662), and Zm (NM_001111991). 


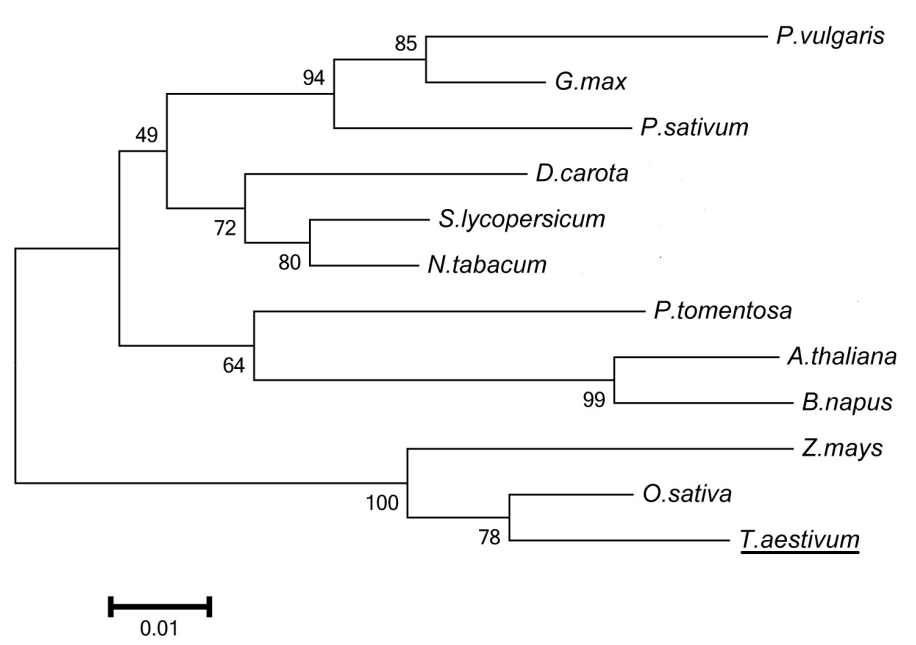

Figure 4. Phylogenetic tree based on the amino acid sequences of TaPCNA from other plants, including TaPCNA (KM087781), Pt (AY836671), Pv (XM_007147532), Gm (NM_001254624), SI (NM_001247915), Dc (Q00268), At (NM_100611), Bn (Q43124), Os (NM_001054973), Ps (O82134), Nt (AJ012662), and Zm (NM_001111991).

\section{Subcellular localization assay}

In order to examine the location of TaPCNA in the cell, we determined the subcellular localization of TaPCNA in a transient expression system, and a GFP-TaPCNA gene fusion construct was transformed into onion epidermal cells. In contrast, cells with the GFP fusion protein alone had signals distributed throughout the cell (Figure 5b), and the GFP-TaPCNA fusion protein expressed under the control of the CaMV35S promoter appeared to accumulate in the nucleus (Figure 5e). Therefore, TaPCNA was localized in the nucleus, which indicates that it may be involved in nuclear DNA metabolism.
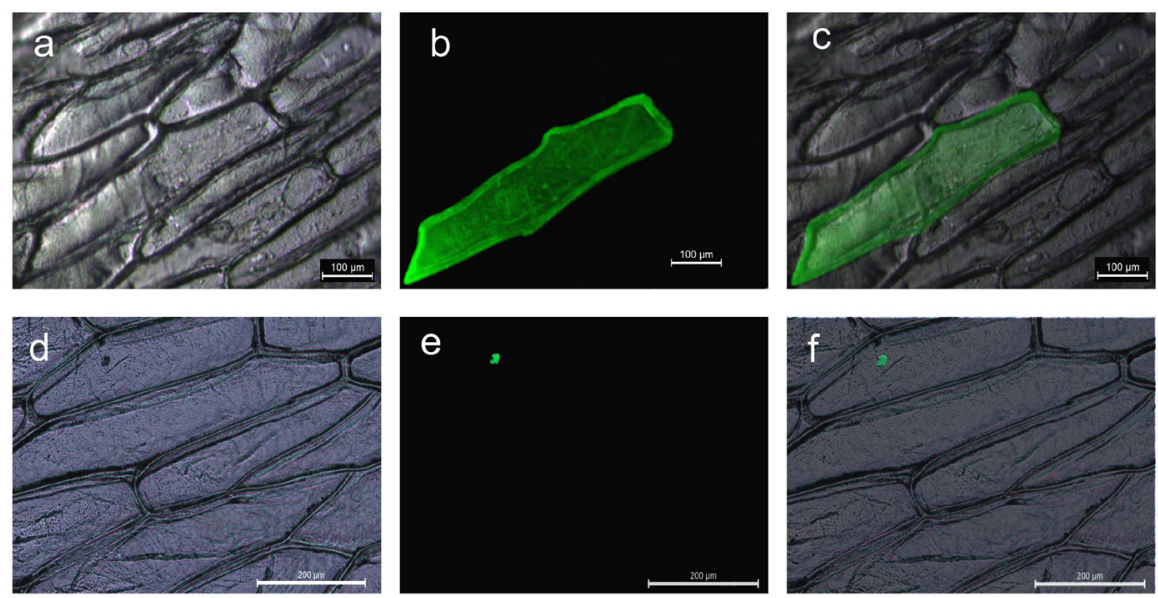

Figure 5. Subcellular localization and expression of TaPCNA. TaPCNA-GFP fusion and GFP plasmids were transformed into onion epidermal cells and examined using a confocal microscope. The photographs were taken in bright light ( $\mathbf{a}$ and $\mathbf{d}$ ), dark field ( $\mathbf{b}$ and $\mathbf{e}$ ), and superimposed (c and $\mathbf{f}$ ). The fusion protein was localized in the nucleus. 


\section{TaPCNA expression analysis}

In order to study the cell cycle, the expression of cell-cycle regulatory genes was evaluated. The well-characterized cell gene Histone $\mathrm{H} 4$ is widely used to predict cell-cycle progression, and its transcription is regarded as a marker of the S-phase in cell division (Reichheld et al., 1995). In our study, we used semi-quantitative RT-PCR to compare the relative expression levels of the cell-cycle regulated gene in 1376-CMIS and 1376. As shown in Figure 6, Histone H4 exhibited low transcript levels in 1376-CMIS in binucleate and trinucleate anthers, suggesting that the expression of Histone $H 4$ is inhibited by SQ-1. However, with pollen development, the TaPCNA transcript levels were higher in 1376-CMIS than in 1376 at all three stages.

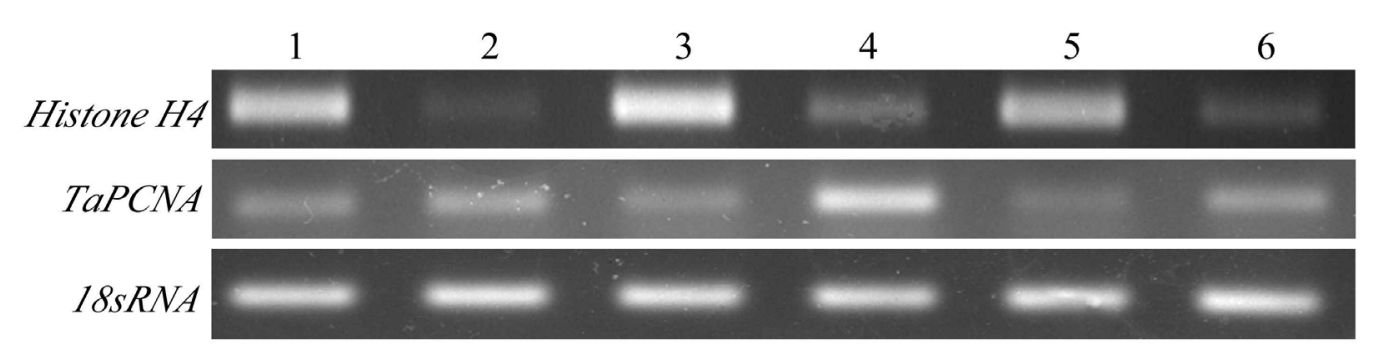

Figure 6. Semi-quantitative reverse transcription polymerase chain reaction analysis of TaPCNA in 1376 and 1376CIMS. Lanes 1 and $2=$ uninucleate stage; lanes 3 and $4=$ binucleate stage; lanes 5 and $6=$ trinucleate stage. Lanes 1,3 , and 5 were 1375 ; lanes 2,4 , and 6 were 1376 -CIMS.

\section{Expression vector construction}

The TaPCNA was amplified by PCR with the primers $\mathrm{P} 3$ and $\mathrm{P} 4$, and the PCR products were cloned into the vector $\mathrm{pGM}^{\otimes}-\mathrm{T}$ and digested with $\mathrm{Sacl}$ and Hindlll, which resulted in two fragments (Figure 2b). A 792-bp fragment was inserted into $\mathrm{pET} 32 \mathrm{a}$ to produce the recombinant plasmid pET32a-TaPCNA. To verify the recombinant plasmid and prevent a false positive caused by the PCR amplification, a double-digestion of the provisionally identified recombinant plasmid $\mathrm{pET} 32 \mathrm{a}-\mathrm{TaPCNA}$ was conducted. The digestion products were a vector fragment of about $5000 \mathrm{bp}$ in length and a TaPCNA fragment that was about $780 \mathrm{bp}$ in length, as was expected (Figure 2c).

\section{Prokaryotic expression and western blotting}

The recombinant plasmid pET32a-PCNA was transformed into E. coli BL21 (DE3) and induced by adding IPTG. The fusion protein was about $50 \mathrm{kDa}$ in Mw (Figure 7). The $\mathrm{Mw}$ of the objective protein was approximately $30 \mathrm{kDa}$, after subtracting $20 \mathrm{kDa}$ of the Histag protein. The Mw was consistent with the theoretical Mw of TaPCNA. For confirmation of the expressed protein, western blot analysis was conducted using an anti-His-tag mouse monoclonal antibody. After visualization with a DAB substrate, a corresponding band was observed (Figure 8), suggesting that TaPCNA can be successfully expressed under the control of a $\mathrm{T} 7$ promoter. 


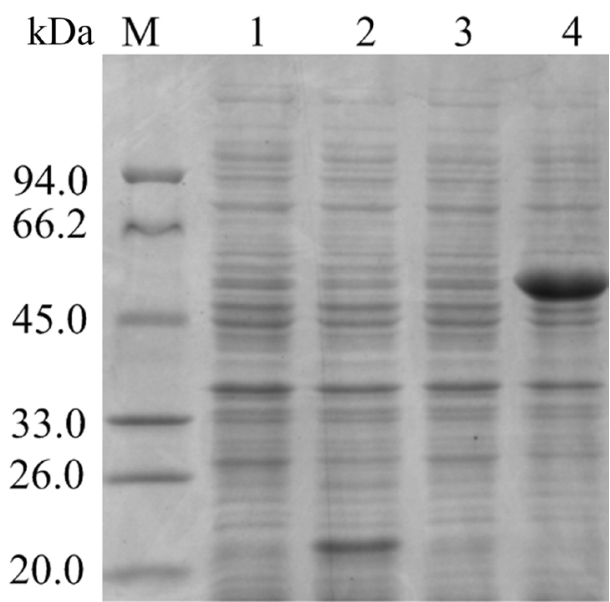

Figure 7. Results of sodium dodecyl sulfate polyacrylamide gel electrophoresis-induced expression of a TaPCNA fusion protein. Lane $M=$ protein marker; lane 1 = control without isopropyl-beta-D-thiogalactopyranoside (IPTG) induction; lane 2 = control induced with $0.5 \mathrm{mM} \mathrm{IPTG}$ for $4 \mathrm{~h}$; lane 3 = recombinant sample without IPTG induction; lane 4 = recombinant sample induced with $0.5 \mathrm{mM}$ IPTG for $4 \mathrm{~h}$.

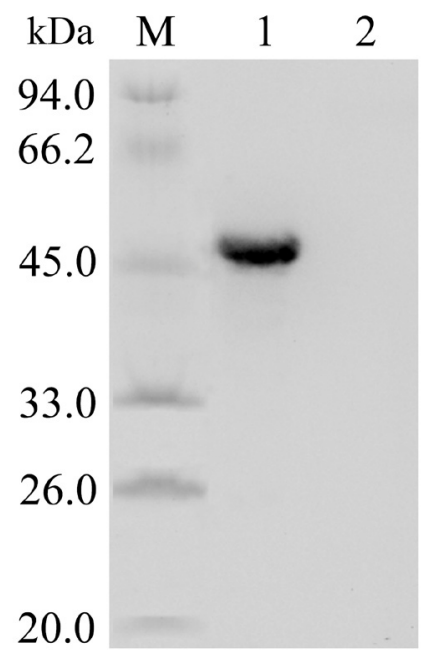

Figure 8. Western blot of the expression product of the recombinant plasmid pET32a-PCNA. Lane $M=$ protein marker; lane 1 = induced recombinant plasmid pET32a-PCNA; lane 2 = uninduced recombinant plasmid pET32a-PCNA.

\section{DISCUSSION}

It is well known that CHAs have deleterious effects on anther growth and development. In our previous study, scanning electron microscopy analysis of 1376 and 1376-CIMS pollen showed that 1376 pollen exhibited a characteristic round and smooth pollen surface, but 1376-CIMS pollen had a completely misshapen and shrunken extine pattern (Ba et al., 2013). After SQ-1 treatment, 
pollen grains fail to develop and remain at the bicellular stage (Zhang et al., 2013). These results demonstrate that SQ-1 has a major impact on the development of pollen and the arrest of the pollen cell-cycle progression. In addition, we demonstrated that 1376-CIMS anthers had higher levels of $\mathrm{O}_{2}, \mathrm{H}_{2} \mathrm{O}_{2}$, and MDA than those of 1376. It has been well documented that abiotic stress dramatically increases the accumulation of ROS, which have destructive effects on lipids, proteins, and nucleic acids. Overproduction of ROS causes oxidative stress, which results in the impairment of membrane integrity and the breakdown of normal cellular functions.

PCNA is an essential protein that is involved in many cellular processes, including DNA replication, DNA repair, and cell-cycle regulation (Strzalka et al., 2010). It is a recognized master coordinator of cellular responses to DNA damage, and interacts with numerous DNA repair and cell-cycle control proteins. The present study provides further evidence that demonstrates the regulatory function of PCNA in DNA damage and repair. It is well known that PCNA plays roles in NER and BER in yeasts and mammals. In rice, X-ray repair cross-complementing 1 (XRCC1), a well-known BER protein, forms a complex with PCNA in DNA repair (Uchiyama et al., 2008).

CIMS is a common phenomenon in higher plants. Although males cannot produce viable pollen, female fertility is unaffected (Ba et al., 2013). In our semi-quantitative RT-PCR assay, we found that Histone $\mathrm{H} 4$ expression was lower in 1376-CMIS than in 1376, indicating that cell-cycle arrest induced by SQ-1 in 1376 anthers was a consequence of DNA damage, and this regulation might be a response to DNA damage. In Arabidopsis, Histone $\mathrm{H} 4$ is downregulated by UV-B radiation, suggesting that UV-B-induced DNA damage results in a delay of the G1-to-S transition in plant cell cycles (Jiang et al., 2011). In addition, TaPCNA expression was higher in 1376-CMIS than in 1376 at all three stages. Therefore, we suggest that TaPCNA plays a key role in the regulation of cell cycle progression in response to DNA repair.

Reformed E. coli has been used extensively as a cellular host for foreign protein expression due to its rapid growth rate, capacity for continuous fermentation, and relatively low cost. In this study, we have shown that TaPCNA can be produced using a prokaryotic expression system. The recombinant vector pET32a-PCNA was transformed in E. coli BL21 (DE3) host cells harboring the phage T7 RNA polymerase, for the expression of heterologous genes. SDS-PAGE and western blot analysis confirmed the expression of the recombinant fusion protein. The TaPCNA fusion protein was successfully expressed using a prokaryotic expression system, which will further elucidate the function of TaPCNA.

\section{CONCLUSION}

In this study, we cloned PCNA from wheat, and the predicted protein consisted of 263 amino acids with a calculated $\mathrm{Mw}$ of $29.16 \mathrm{kDa}$. A subcellular localization assay indicated that TaPCNA is localized to the nucleus, and semi-quantitative RT-PCR results indicated that TaPCNA expression was higher in 1376-CMIS than in 1376 at all three stages. In addition, prokaryotic expression was successfully induced. Taken together, our results increase the understanding of the relationship between the cell cycle and male sterility, and may elucidate how CHAs cause male sterility.

\section{Confilicts of interest}

The authors declare no confilict of interest. 


\section{ACKNOWLEDGMENTS}

Research supported by the National High Technology Research and Development Program of China (\#2011AA10A106), the National Natural Science Foundation of China (\#31171611 and \#31371697), and the Key Scientific and Technological Innovation Special Projects of Shaanxi "13115" (\#2014KTZB02-01-02 and \#2011KTZB02-01-01).

\section{REFERENCES}

Alexander MP (1969). Differential staining of aborted and nonaborted pollen. Stain Technol. 44: 117-122.

Apel K and Hirt H (2004). Reactive oxygen species: metabolism, oxidative stress, and signal transduction. Annu. Rev. Plant Biol. 55: 373-399.

Ba QS, Zhang GS, Wang JS, Che HX, et al. (2013). Relationship between metabolism of reactive oxygen species and chemically induced male sterility in wheat (Triticum aestivum L.). Can. J. Plant Sci. 93: 675-681.

Bartek J, Lukas C and Lukas J (2004). Checking on DNA damage in S phase. Nat. Rev. Mol. Cell Biol. 5: $792-804$.

Chakraborty K and Devakumar C (2005). Quantitative structure-activity relationship analysis as a tool to evaluate the mode of action of chemical hybridizing agents for wheat (Triticum aestivum L.). J. Agric. Food Chem. 53: 3468-3475.

Foyer CH and Noctor G (2000). Oxygen processing in photosynthesis: regulation and signalling. New Phytol. 146: $359-388$.

Friedberg EC, McDaniel LD and Schultz RA (2004). The role of endogenous and exogenous DNA damage and mutagenesis. Curr. Opin. Genet. Dev. 14: 5-10.

Friedberg EC, Lehmann AR and Fuchs RP (2005). Trading places: how do DNA polymerases switch during translesion DNA synthesis? Mol. Cell 18: 499-505.

Hoeijmakers JH (2001). Genome maintenance mechanisms for preventing cancer. Nature 411: 366-374.

Jiang L, Wang Y, Björn LO and Li SS (2011). UV-B-induced DNA damage mediates expression changes of cell cycle regulatory genes in Arabidopsis root tips. Planta 233: 831-841.

Liu HW, Zhang GS, Wang JW, Wang XL, et al. (2003). Effect of male sterility on different wheat genotype induced by SQ-1. J. Northwest A\&F Univ. (Nat. Sci. Edn.) 31: 15-18.

Malan C, Greyling MM, and Gressel J (1990). Correlation between CuZn superoxide dismutase and glutathione reductase and environmental and xenobiotic stress tolerance in maize inbreds. Plant Sci. 69: 157-166.

Matsumoto Y, Kim K and Bogenhagen DF (1994). Proliferating cell nuclear antigen-dependent abasic site repair in Xenopus laevis oocytes: an alternative pathway of base excision DNA repair. Mol. Cell Biol. 14: 6187-6197.

Matsumoto Y, Kim K, Hurwitz J, Gary R, et al. (1999). Reconstitution of PCNA-dependent repair of apurinic/apyrimidinic sites with purified human enzymes. J. Biol. Chem. 274: 33703-33708.

Mittler R, Vanderauwera S, Gollery M and Van Breusegem F (2004). Reactive oxygen gene network of plants. Trends Plant Sci. 9: 490-498.

Moldovan GL, Pfander B and Jentsch S (2007). PCNA, the maestro of the replication fork. Cell 129: 665-679.

Prasad TK, Anderson MD, Martin BA and Stewart CR (1994). Evidence for chilling-induced oxidative stress in maize seedlings and a regulatory role for hydrogen peroxide. Plant Cell 6: 65-74.

Reichheld JP, Sonobe S, Clément B, Chaubet N, et al. (1995). Cell cycle-regulated histone gene expression in synchronized plant cell. Plant J. 7: 245-252.

Sasakuma T, Ahmed T and Tsujimoto H (2001). QTL analysis of fertility-restoration against cytoplasmic male sterility in wheat. Genes Genet. Syst. 76: 33-38.

Stoimenov I and Helleday T (2009). PCNA on the crossroad of cancer. Biochem. Soc. Trans. 37: 605-613.

Strzalka W and Ziemienowicz A (2011). Proliferating cell nuclear antigen (PCNA): a key factor in DNA replication and cell cycle regulation. Ann. Bot. 107: 1127-1140.

Strzalka W, Kaczmarek A, Naganowska B and Ziemienowicz A (2010). Identification and functional analysis of PCNA1 and PCNA-like1 genes of Phaseolus coccineus. J. Exp. Bot. 61: 873-888.

Tsugane K, Kobayashi K, Niwa Y, Ohba Y, et al. (1999). A recessive Arabidopsis mutant that grows enhanced active oxygen detoxification. Plant Cell 11: 1195-1206.

Tuteja N, Singh MB, Misra MK, Bhalla PL, et al. (2001). Molecular mechanisms of DNA damage and repair: progress in plants. Crit. Rev. Biochem. Mol. 36: 337-397.

Uchiyama Y, Suzuki Y and Sakaguchi K (2008). Characterization of plant XRCC1 and its interaction with proliferating cell nuclear antigen. Planta 227: 1233-1241. 
Zhang GS, Chen RH, Ye JX, Wang JS, et al. (2009). Differential proteomic analysis of anther proteins between cytoplasmicnuclear male sterility line and its maintainer in wheat (Triticum aestivum L.). Prog. Biochem. Biophys. 36: 431-440.

Zhang LY, Zhang GS, Zhao XL and Yang SL (2013). Screening and analysis of proteins interacting with TaPDK from physiological male sterility induced by CHA in wheat. J. Integr. Agr. 12: 941-950. 